\title{
Akibat Hukum Perkawinan Janda Yang Dilangsungkan Sebelum Habis Jangka Waktu Tunggu
}

\author{
Nur Reski Lestari \\ Magister Kenotariatan Fakultas Hukum Universitas Airlangga \\ Email : nurreskilestari@gmail.com
}

\begin{abstract}
The purpose of marriage as mentioned in Article 1 of Law Number 1 Year 1974 on Marriage is to establish a happy and eternal family (household) based on Belief in the One Supreme. Sometimes marriage does not go on forever, so there is a divorce. For a wife who breaks up her marriage applies to her waiting period or waiting period, unless a wife divorces her husband before she gets in touch. There are times when a marriage is canceled because it has been known that the waiting period has not been exhausted in a woman. However, on the other hand there is also a problem that marriage has taken place but it turns out the waiting period has not been exhausted. If in the conduct of marriage does not meet the legal requirements of his marriage, then the marriage tersebuh can be canceled. While cancellation can only be done through court decision. When a court decision aborts a marriage, the marriage is considered to have never occurred.

Keywords : Marriage, Waiting period, Marriage Cancellation
\end{abstract}

\begin{abstract}
Abstrak
Tujuan perkawinan sebagaimana disebutkan dalam Pasal 1 UndangUndang Nomor 1 Tahun 1974 tentang Perkawinan adalah membentuk keluarga (rumah tangga) yang bahagia dan kekal berdasarkan Ketuhanan Yang Maha Esa. Adakalanya perkawinan tidak berjalan dengan langgeng, sehingga trjadi perceraian.Bagi seorang istri yang putus perkawinannya berlaku baginya masa tunggu atau masa tunggu, kecuali apabila seorang istri dicerai suaminya sebelum ia berhubungan. Ada kalanya suatu perkawinan dibatalkan karena telah diketahui masa tunggu yang belum habis pada seorang perempuan. Namun, disisi lain juga terdapat suatu masalah bahwasanya perkawinan telah berlangsung namun ternyata masa tunggu tersebut belum habis. Apabila dalam melaksanakan perkawinan tidak memenuhi syarat-syarat sah nya perkawinan, maka perkawinan tersebuh dapat dibatalkan. Sedangkan pembatalan hanya dapat dilakukan melalui putusan pengadilan. Ketika putusan pengadilan
\end{abstract}


Fairness and Justice: Jurnal Ilmiah Ilmu Hukum

p-ISSN: 1858-0106 e-ISSN: 2502-3926

Volume 17 Nomor 1 Mei 2019, Hlm 76-95

http://jurnal.unmuhjember.ac.id/index.php/FAJ

membatalkan perkawinan, maka perkawinan tersebut dianggap tidak pernah terjadi.

Kata Kunci : Perkawinan, Masa Tunggu, Pembatalan Perkawinan

\section{Pendahuluan}

Manusia sebagai makhluk hidup secara kodrati tidak dapat hidup sendiri, sehingga manusia hidup saling membutuhkan satu sama lainnya. Seiring perjalanan kehidupan seorang manusia akan membutuhkan seorang pendamping dalam mengarungi bahtera kehidupan. Seorang manusia akan berusaha menemukan lawan jenis yang bersedia hidup bersama untuk membina rumah tangga dan meneruskan keturunan, sehingga terbentuk suatu keluarga yang bahagia dan harmonis. Keluarga merupakan bagian terkecil dari suatu masyarakat diharapkan dapat menjaga kesinambungan dan kelestarian kehidupan manusia di dunia. Usaha manusia dalam hal menciptakan suatu kehidupan baru bersama dengan pendamping hidupnya lazim disebut sebagai perkawinan. ${ }^{1}$

Perkawinan merupakan salah satu hal penting dalam kehidupan manusia, dalam masyarakat. Melalui perkawinan yang dilakukan menurut aturan hukum yang mengatur mengenai perkawinan ataupun menurut hukum agama masing-masing sehingga suatu perkawinan dapat dikatakan sah, maka pergaulan laki-laki dan perempuan terjadi secara terhormat sesuai kedudukan manusia sebagai mahluk yang bermartabat. Perkawinan merupakan awal dari proses perwujudan dari suatu bentuk kehidupan manusia. Oleh karena itu, perkawinan bukan sekedar pemenuhan kebutuhan biologis semata. Dengan adanya perkawinan, diharapkan dapat tercapai tujuan perkawinan sebagaimana diatur dalam

\footnotetext{
${ }^{1}$ Wahyono Darmabrata, Hukum Perdata Asas-Asas Hukum Orang dan Keluarga, (Jakarta: Gitama Jaya), [27]
} 
Fairness and Justice: Jurnal Ilmiah Ilmu Hukum

p-ISSN: 1858-0106 e-ISSN: 2502-3926

Volume 17 Nomor 1 Mei 2019, Hlm 76-95

http://jurnal.unmuhjember.ac.id/index.php/FAJ

Undang-undang atau aturan hukum dan juga sesuai dengan ajaran agama yang dianut. ${ }^{2}$

Menurut ketentuan Undang Undang Nomor 1 Tahun 1974 bahwa hakikat perkawinan adalah ikatan lahir batin antara seorang pria dan seorang wanita sebagai suami istri. Berdasar rumusan diatas jelaslah bahwa ikatan lahir dan batin harus ada dalam setiap perkawinan. Terjalinnya ikatan lahir dan batin merupakan fondasi dalam membentuk dan membina keluarga yang bahagia dan kekal. Terkait demikian, bahwa hakikat perkawinan itu bukan sekedar ikatan formal belaka, tetapi juga ikatan batin. Hendaknya pasangan yang sudah resmi sebagai suami istri juga merasakan adanya ikatan batin, ini harus ada sebab tanpa itu perkawinan tak akan punya arti, bahkan akan menjadi rapuh. Adanya hal tersebut serta tujuan membentuk keluarga yang bahagia dan kekal, maka suatu tindakan yang akan mengakibatkan putusnya suatu perkawinan (dalam hal ini yang dimaksud adalah perceraian) harus benar-benar dipikirkan serta dipertimbangkan masak-masak.

Ketika konflik berlanjut, masing-masing pihak bersikeras pada pendirian masing-masing untuk berpisah. Sehingga peceraian adalah jalan terakhir yang dapat ditempuh. Bagi seorang istri yang putus perkawinannya berlaku baginya masa tunggu atau masa tunggu, kecuali apabila seorang istri dicerai suaminya sebelum ia berhubungan. Ada kalanya suatu perkawinan dibatalkan karena telah diketahui masa tunggu yang belum habis pada seorang perempuan. Namun, disisi lain juga terdapat suatu masalah bahwasanya perkawinan telah berlangsung namun ternyata masa tunggu tersebut belum habis. Dewasa ini globalisasi sudah merambas hampir seluruh di wilayah dunia. Perkembangan teknologi yang pesat ini merasuk hingga dalam bidang

2 Abdullah Siddik, Hukum Perkawinan Islam, (Jakarta : Tinta Mas Indonesia), [144] 
Fairness and Justice: Jurnal Ilmiah Ilmu Hukum

p-ISSN: 1858-0106 e-ISSN: 2502-3926

Volume 17 Nomor 1 Mei 2019, Hlm 76-95

http://jurnal.unmuhjember.ac.id/index.php/FAJ

kesehatan. Perkembangan teknologi yang pesat tentu membawa dampak positif bagi perkembangan kesehatan yang ada. Berbagai penemuanpenemuan dan temuan baru terus bermunculan melalui berbagai jenis penelitian untuk perkembangan ilmu kesehatan itu sendiri. Salah satunya adalah teknologi untuk menentukan masa tunggu seorang wanita Namun dengan sering kemajuan teknologi memungkinkan masa tunggu tersebut dilanggar.

Bahwa sesuai dengan terjemahan Al-Quran Surat Al-Baqoroh ayat 228 mengatur tentang masa tunggu menjelaskan :"Wanita-wanita yang ditalak hendaklah menahan diri (menunggu) tiga kali quru'. Tidak boleh mereka menyembunyikan apa yang diciptakan Allah dalam rahimnya, jika mereka beriman kepada Allah dan Hari Akhirat. Dan suami-suaminya berhak merujukinya dalam masa menanti itu, jika mereka (para suami) menghendaki ishlah. Dan para wanita mempunyai hak yang seimbang dengan kewajibannya menurut cara yang ma'ruf. Akan tetapi para suami, mempunyai satu tingkatan lebih daripada istrinya. Dan Allah Mahaperkasa lagi Mahabijaksana." (QS. AlBaqarah: 228).

Pencatatan perkawinan bertujuan untuk menjamin ketertiban dan kepastian hukum sebagai sarana pembuktian dalam sebuah perkawinan. Dengan memenuhi seluruh syarat perkawinan maka tujuan perkawinan akan tercapai yakni membentukkeluarga yang bahagia dan utuh. Apabila dalam melaksanakan perkawinan tidak memenuhi syarat-syarat sah nya perkawinan, maka perkawinan tersebuh dapat dibatalkan. Sedangkan pembatalan hanya dapat dilakukan melalui putusan pengadilan. Ketika putusan pengadilan membatalkan perkawinan, maka perkawinan tersebut dianggap tidak pernah terjadi. Pengaturan pembatal perkawinan diatur dalam Pasal 22 sampai dengan Pasal 28 Undang-Undang Perkawinan. Pada Putusan Pengadilan Agama Nomor : 
Fairness and Justice: Jurnal Ilmiah Ilmu Hukum

p-ISSN: 1858-0106 e-ISSN: 2502-3926

Volume 17 Nomor 1 Mei 2019, Hlm 76-95

http://jurnal.unmuhjember.ac.id/index.php/FAJ

0396/Pdt.P/2014/PA.TA dilangsungkannya perkawinan meskipun pada kenyataannya masa tunggu dari perempuan sebagai pemohon perkara belum habis. Dalam hal ini KUA menolak perkawinan tersebut disebabkan masa tunggu pemohon belum habis karena masih dalam keadaan hamil. Dalam putusan ini, hakim mengabulkan permohonan pernikahan dari pemohon dengan landasan bahwa untuk menghitung masa tunggu pemohon bukan didasarkan tunggu hamil. Namun didasarkan karena kehamilan pemohon adalah hasil biologis dengan calon suaminya. Sedangkan pada Putusan Pengadilan Agama Nomor : 0564/Pdt.G/2008/PA.Mr menjatuhkan putusan pembatalan perkawinan yang tejadi pada perempuan dan laki-laki yang telah melangsungkan perkawinan selama 3 bulan. Pembatalan ini dikarenakan diperoleh temuan adanya persyaratan pernikahan yang belum habis masa tunggu. Sehingga, Akta Nikah dan Kutipan Akta dari kedua belah pihak tidak mempunyai kekuatan hukum.

\section{Metode Penelitian}

Untuk kebenaran atas suatu karya ilmiah maka di dalam penelitian harus menggunakan sebuah metodologi yang tepat, karena hal tersebut merupakan pedoman yang menentukan akan kualitas hasil yang didapatkan atas suatu penelitian. Berdasar atas pendapat di atas, penelitian tentang perlindungan hukum keterwakilan perempuan dalam pemilihan umum legislatif dalam tata hukum di Indonesia merupakan penelitian yuridis normatif. Penelitian yuridis normatif merupakan penelitian kepustakaan yang menggunakan sumber bahan hukum kepustakaan. ${ }^{3}$

\footnotetext{
${ }^{3}$ Sidi Alkahfi Setiawan. 2013. Perlindungan Hukum Pekerja Pemegang Saham Di PT Bank Central Asia Tbk. Fakultas Hukum Universitas Jember. Jember. hlm. 18
} 
Fairness and Justice: Jurnal Ilmiah Ilmu Hukum

p-ISSN: 1858-0106 e-ISSN: 2502-3926

Volume 17 Nomor 1 Mei 2019, Hlm 76-95

http://jurnal.unmuhjember.ac.id/index.php/FAJ

\section{Hasil dan Pembahasan}

\subsection{Ratio Decindenci Hakim dalam Menolak dan Mengabulkan Pelaksanaan Perkawinan}

Bentuk penyelesaian perkara di pengadilan dibedakan atas dua macam, yakni putusan atau vonis dan penetapan atau beschikking. Putusan adalah penyataan hakim yang dituangkan dalam bentuk tertulis dan diucapkan oleh hakim dalam sidang terbuka untuk umum sebagai hasil dari pemeriksaan perkara gugatan (kontentius). ${ }^{5}$ Penetapan adalah pernyataan hakim yang dituangkan dalam bentuk tertulis dan diucapkan oleh hakim dalam sidang terbuka untuk umum sebagai hasil dari pemeriksaan permohonan (voluntair). ${ }^{6}$ Sehingga terdapatperbedaan antara gugatan dan permohonan, yaitu dalam perkara gugatan ada sengketa atau konflik yang harus diselesaikan dan diputus oleh pengadilan, sedangkan dalam perkara yang disebut permohonan tidak ada sengketa. ${ }^{7}$

Pengadilan Agama merupakan salah satu institusi penyelenggaraan kekuasaan kehakiman di Indonesia yang berfungsi untuk memeriksa serta mengadili berbagai macam sengketa perkawinan dan kekeluargaan bagi masyarakat yang beragama Islam. Adanya peradilan yang bebas dan tidak memihak (independent and impartial judiciary). Peradilan bebas dan tidak memihak ini mutlak harus ada dalam setiap negara hukum. Dalam menjalankan tugas judicialnya, hakim tidak boleh dipengaruhi oleh siapun juga, baik karena kepentingan jabatan (politik) maupun

${ }^{4}$ Makarao, Taufik, Pokok-Pokok Hukum Acara Perdata, (Rineka Cipta, Jakarta), [126].

${ }^{5} \mathrm{Hj}$. Atifaturrahmaniyah (Wakil Ketua Pengadilan Agama Surabaya), Hukum Acara Peradilan Agama, bahan ajar disampaikan pada Pendidikan Khusus Profesi Advokad (PKPA) yang diselenggarakan oleh Perhimpunan Advokad Indonesia (PERADI) dengan Universitas Airlangga Surabaya pada 7 April 2016.

6 Ibid.

7 Sutantio, Retnowulan dan Iskandar Oeripkartawinata, Hukum Acara Perdata dalam Teori dan Praktek, (Mandar Maju, Bandung, 2005), [10]. 
Fairness and Justice: Jurnal Ilmiah Ilmu Hukum

p-ISSN: 1858-0106 e-ISSN: 2502-3926

Volume 17 Nomor 1 Mei 2019, Hlm 76-95

http://jurnal.unmuhjember.ac.id/index.php/FAJ

kepentingan uang (ekonomi). Untuk menjamin keadilan dan kebenaran, tidak diperkenankan adanya intervensi ke dalam proses pengambilan putusan keadilan oleh hakim, baik intervensi dari lingkungan kekuasaan eksekutif maupun legislatif ataupun dari kalangan masyarakat dan media massa $^{8}$. Dalam menjalankan tugasnya, hakim tidak boleh memihak siapapun juga kecuali hanya pada kebenaran dan keadilan. Namun demikian, dalam menjalankan tugasnya proses pemeriksaan perkara oleh hakim harus bersifat terbuka, dan dalam menentukan penilaian dan menjatuhkan putusan hakim harus menghayati nilai-nilai keadilan yang hidup di tengah-tengah masyarakat. Hakim tidak hanya bertindak sebagai mulut undang-undang atau peraturan perundang-undangan, melainkan juga mulut keadilan yang menyuarakan perasaan keadilan yang hidup di tengah-tengah masyarakat.

Pengadilan Agama merupakan salah satu institusi penyelenggaraan kekuasaan kehakiman di Indonesia yang berfungsi untuk memeriksa serta mengadili berbagai macam sengketa perkawinan dan kekeluargaan bagi masyarakat yang beragama Islam. Dikarenakan profesi hakim dalam tradisi Islam merupakan merupakan profesi mujtahid. Oleh karena itu, hakim dalam pengadilan agama berpeluang besar untuk berperan dalam menemukan, merumuskan, dan menetapkan hukum dalam praktik di lingkungan lembaga peradilan. ${ }^{9}$ Sedangkan hakim pengadilan agama wajib menyelesaikan perkara-perkara di bidang perkawinan, kewarisan, wasiat dan hibah yang dilakukan berdasarkan hukum Islam, serta wakaf dan shodaqoh sebagaimana tercantum dalam Pasal 49 Undang-Undang Nomor 50 Tahun 2010 tentang Peradilan Agama.

\footnotetext{
8 Asshiddiqie, Jimly, Konstitusi dan Konstitusionalisme Indonesia, (Sinar Grafika, Jakarta), [130]

9 Mustofa, Abdul Wahid, Hukum Islam Kontemporer, (Sinar Grafika, Jakarta), [140].
} 
Fairness and Justice: Jurnal Ilmiah Ilmu Hukum

p-ISSN: 1858-0106 e-ISSN: 2502-3926

Volume 17 Nomor 1 Mei 2019, Hlm 76-95

http://jurnal.unmuhjember.ac.id/index.php/FAJ

\subsection{Fungsi dan Peranan Hakim dalam Pembentukan Hukum Melalui Putusan Pengadilan}

Berdasarkan Pasal 2 Ayat 1 Undang-Undang Kekuasaan Kehakiman, dinyatakan bahwa peradilan dilakukan demi keadilan berdasarkan Ketuhanan Yang Maha Esa. Serta pada Pasal 5 di undang-Undang yang sama, menyatakan bahwa hakim dan hakim konstitusi wajib menggali, mengikuti, dan memahami nilai-nilai hukum dan rasa keadilan yang hidup dalam masyarakat. Sehingga dapat dikatakan bahwa lembaga peradilan yang ada di Indonesia harus memiliki sifat menjamin sikap tidak memihak (tidak membeda-bedakan orang), adil, jujur, netral dan bebas. Sebagai pelaksana dari kekuasaan kehakiman adalah hakim, yang mempunyai kewenangan dalam memberi isi dan kekuatan kepada normanorma hukum dalam peraturan perundang-undangan yang berlaku, dan hal ini dilakukan oleh hakim melalui putusan mapun penetapannya. Fungsi utama dari seorang hakim adalah memberikan putusan terhadap perkara yang diajukan kepadanya dengan ditentukan berdasarkan keyakinan hakim yang dilandasi dengan integritas dan moral yang baik. ${ }^{10}$ Jadi putusan hakim bukanlah semata-mata didasarkan pada ketentuan yuridis saja, melainkan juga didasarkan pada hati nurani. Memeriksa dan memutus suatu perkara bukanlah suatu pekerjaan yang mudah.

Hakim sebagai organ badan peradilan dilarang untuk menolak memeriksa dan mengadili suatu perkara yang diajukan dengan dalih bahwa hukum tidak ada atau tidak jelas dasar hukumnya, melainkan wajib untuk memeriksa dan mengadilinya. ${ }^{11}$ Hal tersebut secara tidak

10 Sujana, Nyoman, Kedudukan Hukum Anak Luar Kawin Dalam Perspektif Putusan Mahkamah Konstitusi Nomor 46/PUU-VII, (Aswaja Pressindo, Yogyakarta), [193]

11 Waluyo, Bambang, Implementasi Kekuasaan Kehakiman Republik Indonesia, (Sinar Grafika, Jakarta), [11] 
Fairness and Justice: Jurnal Ilmiah Ilmu Hukum

p-ISSN: 1858-0106 e-ISSN: 2502-3926

Volume 17 Nomor 1 Mei 2019, Hlm 76-95

http://jurnal.unmuhjember.ac.id/index.php/FAJ

langsung menjadikan fungsi dari adanya badan peradilan, yaitu untuk menemukan maupun membentuk hukum yang tidak bertentangan dengan rasa keadilan masyarakat, karena dipundak hakimlah diletakkan kewajiban dan tanggung jawab agar hukum dan keadilan ditegakkan atau sebagai pelaksana penegakkan hukum judiciary as the upholders of the rule of law. ${ }^{12}$ Andaikata hakim tidak mampu menemukan hukum tertulis, maka ia wajib untuk menggali hukum tidak tertulis untuk memutus berdasarkan hukum sebagai seorang yang bijaksana dan bertanggungjawab penuh kepada Tuhan Yang Maha Esa, diri sendiri, masyarakat, Bangsa dan Negara. ${ }^{13}$

Peranan Hakim sebagai aparat Kekuasaan Kehakiman pasca Undang-Undang Republik Indonesia Nomor 3 Tahun 2006 tentang Perubahan atas Undang-Undang Nomor 7 Tahun 1989 tentang Peradilan Agama, pada prinsipnya tugas hakim adalah melaksanakan fungsi peradilan sesuai dengan ketentuan peraturan yang berlaku.dalam menjalankan fungsi peradilan ini tugas hakim menegakkan hukum dan keadilan. Sehubungan dengan hal tersebut, dalam menjatuhkan putusan hakim harus memperhatikan tiga hal yang esensial, yaitu keadilan (gerechtigheit), kemanfaatan (zwachmatighei) dan kepastian (rechsecherheit). ${ }^{14}$ Ketiga asas tersebut harus dilaksakan secra kompromi yaitu dengan cara menerapkan ketiga-tiganya secara berimbang dan proporsional. Sehingga putusan tidak menimbulkan kekacauan dan keresahan bagi masyarakat, terutama bagi perncari keadilan. ${ }^{15}$

\footnotetext{
${ }^{12}$ M. Harahap, Yahya, Op. Cit, [6]

${ }^{13}$ Waluyo, Bambang, Loc. Cit.,

14 Manan, Abdul, Penerapan Hukum Acara Perdata di Peradilan Agama, (Kencana, Jakarta), [291].

${ }^{15}$ Mertokusumo, Sudikno dan A.Pilto, Bab-Bab Tentang Penemuan Hukum, (Citra Adiya Bakti, Jakarta),[2].
} 
Fairness and Justice: Jurnal Ilmiah Ilmu Hukum

p-ISSN: 1858-0106 e-ISSN: 2502-3926

Volume 17 Nomor 1 Mei 2019, Hlm 76-95

http://jurnal.unmuhjember.ac.id/index.php/FAJ

Hakim merupakan organ utama dalam suatu pengadilan dan sebagai pelaksana kekuasaan kehakiman yang dianggap memahami hukum untuk dapat menerima, memeriksa dan mengadili suatu perkara sesuai dengan Pasal 10 Ayat 1 Undang-Undang Kekuasaan Kehakiman, sehingga dengan demikian wajib hukumnya bagi hakim untuk dapat menemukan hukum, baik melalui hukum tertulis maupun tidak tertulis untuk memutuskan suatu perkara berdasarkan hukum sebagai seorang yang bijaksana dan bertanggungjawab. ${ }^{16}$

Tujuan diadakannya suatu proses di muka Pengadilan adalah untuk memperoleh putusan Hakim yang mempunyai kekuatan hukum yang tetap, artinya suatu putusan yang tidak dapat diubah lagi. Hakim wajib mengadili segala bagian dari tuntutan penggugat dan ia tidak boleh memberi putusan tentang hal-hal yang tidak dituntut atau meluliskan lebih dari yang dituntut. Untuk dapat menyelesaikan atau mengakhiri suatu perkara secara tepat, Hakim harus terlebih dahulu mengetahui secara obyektif tentang duduk perkara sebagai dasar putusan dan bukan sebagai apriori menemukan putusannya. ${ }^{17}$

Fungsi dan tugas pokok penegakan hukum dan keadilan bagi hakim, yaitu menentukan hukum dan keadilan setelah terjadi kasus-kasus nyata dan konkret. Dengan putusannya, hakim menciptakan yurisprudensi yang merupakan pula salah satu sumber hukum. ${ }^{18}$ Dalam menyelesaikan suatu perkara, putusan pengadilan harus adil dan memiliki kepastian hukum. Selain bermanfaat bagi para pihak terkait, putusan pengadilan juga harus bermanfaat bagi masyarakat luas. Putusan pengadilan merupakan suatu pernyataan oleh hakim sebagai pejabat negara yang

${ }^{16}$ Rifa'i, Ahmad, Penemuan Hukum oleh Hakim, (Sinar Grafika, Jakarta), [26].

${ }^{17}$ Rasaid,M. Nur, Hukum Acara Perdata, (Sinar Grafika, Jakarta), [48]

18 Hamami, Taufik, Kedudukan dan Eksistensi Peradilan Agama Dalam Sistem Tata Hukum di Indonesia, (Alumni, Bandung,), [266]. 
Fairness and Justice: Jurnal Ilmiah Ilmu Hukum

p-ISSN: 1858-0106 e-ISSN: 2502-3926

Volume 17 Nomor 1 Mei 2019, Hlm 76-95

http://jurnal.unmuhjember.ac.id/index.php/FAJ

diberi wewenang untuk memeriksa dan mengadili terhadap suatu perkara supaya dapat diperoleh penyelesaian yang adil berdasarkan perundang-undangan.

Suatu putusan hakim didasari pertimbangan atau konsideran. Pertimbangan hakim dalam suatu putusan perdata dibagi menjadi 2 (dua) yaitu pertimbangan mengenai duduk perkara atau peristiwanya dan tentang pertimbangan hukum. Dalam pertimbangan putusan hakim yang termuat adalah alasan-alasan hakim sebagai tanggung jawabnya kepada masyarakat atas putusan yang dijatuhkan, sehingga mempunyai nilai obyektif. Alasan dan dasar dari putusan harus dimuat dalam pertimbangan putusan. ${ }^{19}$

Pertimbangan hakim dan putusan merupakan satu kesatuan yang utuh dan tidak dapat dipisahkan. Bahkan putusan dianggap cacat jika tidak memuat pertimbangan-pertimbangan yang cukup matang. Pertimbangan hakim sendiri terdiri alasan memutus yang biasanya dimulai dengan kata menimbang dan dasar memutus yang biasanya dimulai dengan kata mengingat. Pada alasan memutus maka apa yang diutarakan dalam bagian-bagian duduk perkara nya terdahulu, yaitu keterangan pihak-pihak berikut dalil-dalil nya. Alat bukti yang diajukan juga harus dipertimbangkan semuanya dengan seksama satu per satu, tidak boleh ada yang luput dari pertimbangan. Pertimbangan terakhir adalah pihak yang mana yang akan dinyatakan sebagai pihak yang dibebankan untuk memikul biaya perkara karena kalah.

Konsekuensi selanjutnya yang harus ditegakkan atas keberadaan dan kemandirian kekuasaan kehakiman yang dilaksanakan peradilan, putusan yang dijatuhkan hakim melalui badan peradilan antara lain dikatakan sama dengan putusan Tuhan, sehingga putusan yang

${ }^{19}$ Mertokusumo, Sudikno, Hukum Acara Perdata Indonesia, (Liberty, Yogyakarta), [183]. 
Fairness and Justice: Jurnal Ilmiah Ilmu Hukum

p-ISSN: 1858-0106 e-ISSN: 2502-3926

Volume 17 Nomor 1 Mei 2019, Hlm 76-95

http://jurnal.unmuhjember.ac.id/index.php/FAJ

dijatuhkan melalui badan peradilan adalah judicium dei atau judicium atau "the judgment was that og god"20 sehingga apabila putusan yang dijatuhkan hakim melalui peradilan telah memperoleh kekuatan hukum yang tetap , putusan itu tidak dapat diganggu gugat lagi. Siapapun itu tidak akan dapat merubahnya. Putusan tersebut harus dilaksanakan walaupun kejam dan tidak menyenangkan. ${ }^{21}$

\subsection{Penetapan Pengadilan Agama Nomor : 0369/Pdt.P/2014/PA.TA}

Bahwa pemohon adalah seorang janda yang merupakan calon istri dari laki-laki calon suami pemohon. Pemohon berstatus janda cerai sebagaimana tercantum dalam akta cerai yang dikeluarkan oleh Panitera Pengadilan Agama Tulungagung tanggal 21 Mei 2014, Nomor : 1115/AC/2014/PA.TA. Pemohon tersebut bercerai dengan suaminya dengan cerai talak dan dalam keadaan suci ba'da dukhul dengan masa tunggu terhitung sejak terjadinya perceraian tanggal 21 Mei 2014. Pemohon telah mengenal calon suami pemohon kurang lebih 1 Tahun atau sebelum pemohon bercerai dengan suaminya terdahulu dan telah melakukan hubungan layaknya suami isteri hingga pemohon tersebut hamil 16 minggu atau 4 bulan, sebagaimana tercantum dalam surat keterangan kesehatan dari Puskesmas Pakel tertanggal 15 November 2014. Masa tunggu dari pemohon tersebut berakhir pada tanggal 30 September 2014 dan pemohon ingin menikah dengan calon suami pemohon dihadapan Pegawai Pencatat Nikah pada Kantor Urusan Agama Kecamatan Kabupaten Tulungagung. Persyaratan untuk melangsungkan perkawinan antara pemohon dengan calon suami pemohon sebagaimana diatur dalam Undang-Undang Perkawinan telah terpenuhi semua.

${ }^{20}$ Harahap, Yahya, Op.Cit, [11]

${ }^{21}$ Peraturan Menteri Negara Agraria/Kepala Badan Pertanahan Nasional Nomor 9 Tahun 1999 Pasal 4. 
Fairness and Justice: Jurnal Ilmiah Ilmu Hukum

p-ISSN: 1858-0106 e-ISSN: 2502-3926

Volume 17 Nomor 1 Mei 2019, Hlm 76-95

http://jurnal.unmuhjember.ac.id/index.php/FAJ

Namun, Pegawai Pencatat Nikah pada Kantor Urusan Agama Kabupaten Tulungagung menolak untuk melangsungkan pernikahan pemohon dengan calon suami pemohon dengan alasan adanya halangan atau kekurangan persyaratan pernikahan sebagaimana tercantum dalam Surat Kepala Kantor Urusan Agama tanggal 25 November 2014 Nomor : KK.15.04.03/PW.01/294/2014 tentang pemberitahuan adanya halangan/kekurangan persyaratan perkawinan dan tanggal 25 November 2014 tentang penolakan perkawinan, serta penjelasan Kepala Kantor Urusan Agama tersebut tentang masa tunggu pemohon yang belum habis karena masih dalam keadaan hamil. Dalam hal ini pemohon keberatan atas surat penolakan Pegawai Pencatat Nikah pada Kantor Urusan Agama yang menolak untuk melangsungkan perkawinan pemohon dengan calon suami pemohon karena antara pemohon dan calon suami pemohon tidak ada halangan untuk melangsungkan perkawinan baik menurut ketentuan agama maupun peraturan yang berlaku. Dalam hal ini calon suami pemohon bertanggung jawab atas hamilnya pemohon serta ingin segera melangsungkan perkawinan, karena nikah hamil tidak dilarang/dibenarkan menurut ketentuan Pasal 53 Kompilasi Hukum Islam. Dasar dari pemohon yang ingin segera melangsungkan perkawinan adalah agar anak yang didalam kandungan kelak lahir dalam pernikahan yang sah.

Selain dari bukti-bukti tertulis, pemohon juga menghadirkan 2 orang saksi. Saksi pertama adalah tetangga dekat dan mengetahui bawa pemohon hendak melangsungkan perkawinan dengan calon suami namun ditolak oleh Pegawai Kantor Urusan Agama yang tidak mau mengawinkan serta mencatatkan perkawinannya tersebut. Saksi juga memahami bahwa penolakan dari Kantor Urusan Agama karena pemohon masih dalam masa tunggu dengan suaminya terdahulu, 
Fairness and Justice: Jurnal Ilmiah Ilmu Hukum

p-ISSN: 1858-0106 e-ISSN: 2502-3926

Volume 17 Nomor 1 Mei 2019, Hlm 76-95

http://jurnal.unmuhjember.ac.id/index.php/FAJ

sehingga harus menunggu kelahiran anaknya terlebih dahulu. Saksi tersebut juga mengetahui bahwa pemohon dengan mantan suaminya telah bercerai sejak Mei 2014 dan beberapa bulan sebelum bercerai, mereka telah pisah tempat tinggal sehingga mereka tidak pernah bertemu ataupun melakukan hubungan suami isteri. Saksi juga mengetahui bahwa hubungan pemohon dengan calon suami pemohon sangat akrab dan dekat hingga saat ini pemohon hamil 4 bulan. Saksi juga mengetahui bahwa kehamilan pemohon tersebut hanya dengan calon suami pemohon bukan dengan mantan suami nya. Saksi mengetahui bahwa antara pemohon dengan calon suami pemohon tidak ada hubungan darah maupun sepersusuan. Saat ini pemohon juga tidak sedang dalam pinangan laki-laki lain.

Saksi yang kedua adalah teman dekat calon suami pemohon. Saksi mengetahui bahwa pemohon hendak melangsungkan perkawinan dengan pemohon, namun ditolak oleh pegawai Kantor Urusan Agama dengan dalih tidak mau mengawinkan dan juga tidak mau mencatatkan. Saksi mengetahui bahwa alasan penolakan karena pemohon masih dalam masa tunggu dengan suaminya terdahulu yang bercerai sejak Mei 2014. Majelis Hakim mengabulkan permohonan dari pemohon dengan menyatakan surat penolakan perkawinan yang dikeluarkan oleh Kantor Urusan Agama Kecamatan Kabupaten Tulungagung karena dinilai tidak mempunyai alasan hukum. Apabila ditelaah kembali berdasarkan waktu cerai pemohon dengan habisnya waktu tunggu kawin terhitung habis tanggal 30 September 2014. Berdasarkan Pasal 11 Undang-Undang Perkawinan jo Pasal 39 Ayat 1 (b) Peraturan Pemerintah Nomor 9 Tahun 1975 tentang Pelaksanaan Undang-Undang Perkawinan ditegaskan bawa apabila perkawinan putus karena perceraian, waktu tunggu bagi yang masih berdatang bulan adalah 3 (tiga) kali suci dengan sekurang- 
Fairness and Justice: Jurnal Ilmiah Ilmu Hukum

p-ISSN: 1858-0106 e-ISSN: 2502-3926

Volume 17 Nomor 1 Mei 2019, Hlm 76-95

http://jurnal.unmuhjember.ac.id/index.php/FAJ

kurangnya 90 (sembilan puluh) hari dan bagi yang tidak berdstang bulan ditetapkan 90 (sembilan puluh) hari. Dengan demikian, waktu tunggu pemohon telah habis dan dapat melangsungkan perkawinan kembali. Menilik kembali ke Pasal 53 Kompilasi Hukum Islam mengenai kawin hamil, seorang wanita yang hamil di luar nikah dapat dikawinkan dengan pria yang menghamilinya tanpa menunggu lebih dahulu kelahiran dari anaknya. Dengan demikian, tidak diperlukan perkawinan lagi setelah anak kandungannya tersebut lahir.

\subsection{Putusan Pengadilan Agama Nomor : 0564/Pdt.G/2008/PA.Mr}

Berdasarkan permohonan pemohon tersebut, Termohon 1 dan Termohon 2 telah memberikan jawaban secara lisan yang pada pokoknya mengakui kebenaran atas semua dalil permohonan pemohon dan menyatakan tidak keberatan atas permohonan tersebut. Pihak termohon juga mengakui apabila pemeriksaan dari Urusan Agama Islam dan Pembinaan Syariah Departemen Agama Kabupaten Mojokerto benar adanya kesalahan penghitungan waktu tunggu kawin. Menimbang bahwa alasan pemohon telah diakui dan dibenarkan oleh termohon 1 dan termohon 2. Maka sesuai ketentuan Pasal 174 H.I.R yang berbunyi : Pengakuan yang diucapkan dihadapan hakim, menjadi bukti yang cukup untuk memberatkan orang yang mengaku itu, baik pengakuan itu diucapkan sendiri, maupun diucapkan oleh seseorang yang istimewa yang dikuasakan untuk melakukannya. Dimana pengakuannya tersebut merupakan bukti sempurna dan sah menurut hukum, oleh karena nya harus diterima.

Menimbang kembali dalil-dalil permohonan pemohon yang dikuatkan surat bukti Foto copy kutipan akta nikah atas nama termohon 1 dan termohon 2 dari Kantor Urusan Agama Kecamatan Jetis Kabupaten 
Fairness and Justice: Jurnal Ilmiah Ilmu Hukum

p-ISSN: 1858-0106 e-ISSN: 2502-3926

Volume 17 Nomor 1 Mei 2019, Hlm 76-95

http://jurnal.unmuhjember.ac.id/index.php/FAJ

Mojokerto dan Foto Copy Akta Cerai atas nama Termohon 2 tidak diajukan keberatan baik Termohon 1 maupun Termohon 2. Hal tersebut telah menunjukkan kebenaran atas pemohon yang tertuang dalam surat permohonannya.

Menimbang bahwa merujuk ketentuan Peraturan Pemerintah Nomor 9 Tahun 1975 Pasal 34 Ayat 2 yang berbunyi, suatu perceraian dianggap terjadi beserta segala akibat-akibatnya terhitung sejak saat pendaftarannya pada daftar pencatatan kantor pencatatan oleh Pegawai Pencatat, kecuali mereka yang beragama Islam terhitung sejak jatuhnya putusan Pengadilan Agama yang telah mempunyai kekuatan hukum tetap dan Pasal 39 Ayat 1 huruf b yang berbunyi, apabila perkawinan putus karena perceraian, waktu tunggu bagi yang masih berdatang bulan adalah 3 kali suci dengan sekurang-kurangnya 90 (sembilan puluh) hari dan bagi yang mereka tidak berdatang bulan ditetapkan 90 (sembilan puluh) hari. Artinya, perceraian dianggap terjadi serta segala akibatakibatnya bagi mereka yang beragama Islam terhitung sejak jatuhnya putusan pengadilan yang telah mempunyai kekuatan hukum tetap dan waktu tunggu nya bagi yang masih berdatang bulan ditetapkan 3 kali suci atau 90 hari dan bagi yang tidak berdatang bulan adalah 90 hari.

Majelis Hakim menilai bahwa perkawinan yang dilakukan termohon 1 dan termohon 2 yang dilaksanakan pada tanggal 7 Januari 2008 tidak memenuhi syarat. Ini disebabkan karena waktu tunggu termohon 2 masih belum habis. Berdasarkan pasal 22 Undang-Undang Perkawinan dijelaskan bawa perkawinan dapat dibatalkan apabila para pihak tidak memenuhi syarat-syarat untuk melangsungkan perkawinan. Demikian juga dijelaskan dalam Pasal 71 huruf c Kompilasi Hukum Islam yang menyebutkan bahwa suatu perkawinan dapat dibatalkan apabila perempuan yang dikawini ternyata masih dalam iddah/waktu tunggu 
Fairness and Justice: Jurnal Ilmiah Ilmu Hukum

p-ISSN: 1858-0106 e-ISSN: 2502-3926

Volume 17 Nomor 1 Mei 2019, Hlm 76-95

http://jurnal.unmuhjember.ac.id/index.php/FAJ

dari suami lain. Melihat dari tegasnya peraturan perundang-undangan tersebut maka permohon dari pemohon dikabulkan. Sehingga perkawinan dari termohon 1 dan termohon 2 dibatalkan, dan dinyatakan akta nikah beserta kutipan yang dikeluarkan oleh Pegawai Pencatat Nikah tersebut tidak mempunyai kekuatan hukum tetap.

Dampak hukum terhadap pembatalan perkawinan menurut Pasal 28 Ayat 2 Undang-Undang Perkawinan berpengaruh akibat hukumnya terhadap suami isteri. Batalnya perkawinan dimulai setelah jatuhnya putusan pengadilan yang mempunyai kekuatan hukum tetap. Sehingga dengan putusan pengadilan yang menyatakan bahwa perkawinan tersebut dibatalkan maka perkawinan tersebut dianggap tidak pernah terjadi meskipun perkawinan tersebut baru saja dilangsungkan atau telah berlangsung beberapa lama. Dan diharamkan bagi mereka yang perkawinannya telah dibatalkan untuk melakukan hubungan suami istri.

\section{Kesimpulan}

Berdasarkan hasil pembahasan yang telah diuraikan diatas, maka dapat ditarik kesimpulan bahwa pertimbangan hakim dalam putrusan perkara : 0369/Pdt.P/2014/PA.TA telah sesuai dengan regulasi dan peraturan yang berlaku karena berdasarkan pemaparan keterangan para saksi dan bukti-bukti yang disodorkan serta adanya pertimbangan yuridis yang mengacu pada Undang-Undang Perkawinan dan Kompilasi Hukum Islam serta diperkuat dengan keyakinan hakim.

Pertimbangan hukum yang menyebabkan terjadinya pembatalan perkawinan dari Pengadilan Agama adalah karena perkawinan tersebut tidak memenuhi syarat-syarat perkawinan, adanya ketidakjujuran status dari calon mempelai, kurang telitinya pemeriksaan administrasi calon 
Fairness and Justice: Jurnal Ilmiah Ilmu Hukum

p-ISSN: 1858-0106 e-ISSN: 2502-3926

Volume 17 Nomor 1 Mei 2019, Hlm 76-95

http://jurnal.unmuhjember.ac.id/index.php/FAJ

suami isteri serta kurang pahamnya masyarakat terhadap ketentuan hukum Islam bagi yang beragama Islam dan Undang-Undang Perkawinan. Banyak akibat yang ditimbulkan dari suatu proses pembatalan perkawinan. Yang paling menonjol adalah diantara keduanya dianggap tidak pernah terjadi perkawinan. Jadi putusan pengadilan berlaku surut terhadap perkawinan yang telah dibatalkan, maksudnya sejak perkawinan mereka dianggap tidak pernah terjadi. Hal ini sesuai dengan yang tertera dengan Pasal 28 Undang-Undang Perkawinan bahwa keputusan berlaku sejak berlangsungnya perkawinan. Dan hal ini berlangsung setelah pembatalan perkawinan tersebut memperoleh kekuatan hukum yang tetap, yaitu setelah mendapat keputusan pengadilan. 
Fairness and Justice: Jurnal Ilmiah Ilmu Hukum

p-ISSN: 1858-0106 e-ISSN: 2502-3926

Volume 17 Nomor 1 Mei 2019, Hlm 76-95

http://jurnal.unmuhjember.ac.id/index.php/FAJ

\section{Daftar Pustaka}

\section{Buku}

Abdullah Siddik. (1967). Hukum Perkawinan Islam. Jakarta: Tinta Mas Indonesia

Asshiddiqie Jimly. (2012). Konstitusi dan Konstitusionalisme Indonesia. Jakarta: Sinar Grafika

Hamami, Taufik. (2003). Kedudukan dan Eksistensi Peradilan Agama Dalam Sistem Tata Hukum di Indonesia. Bandung: Alumni

Manan Abdul. (2015). Penerapan Hukum Acara Perdata di Peradilan Agama. Jakarta: Kencana

Makarao Taufik. (2016) Pokok-Pokok Hukum Acara Perdata. Jakarta: Rineka Cipta

Mustofa Abdul Wahid. 2005(). Hukum Islam Kontemporer. Jakarta: Sinar Grafika

Mertokusumo, Sudikno dan A.Pilto. (2002). Bab-Bab Tentang Penemuan Hukum. Jakarta: Citra Adiya Bakti

Mertokusumo Sudikno. (2000). Hukum Acara Perdata Indonesia. Yogyakarta: Liberty

Rasaid M. Nur. (2005). Hukum Acara Perdata. Jakarta: Sinar Grafika

Rifa'i Ahmad. (2007). Penemuan Hukum oleh Hakim. Jakarta: Sinar Grafika

Sutantio Retnowulan dan Iskandar Oeripkartawinata. (2005). Hukum Acara

Perdata dalam Teori dan Praktek. Bandung: Mandar Maju

Sujana, Nyoman. (2013). Kedudukan Hukum Anak Luar Kawin Dalam Perspektif Putusan Mahkamah Konstitusi Nomor 46/PUU-VII. Yogyakarta: Aswaja Pressindo

Wahyono Darmabrata. (2009). Hukum Perdata Asas-Asas Hukum Orang dan Keluarga. Jakarta: Gitama Jaya 
Fairness and Justice: Jurnal Ilmiah Ilmu Hukum

p-ISSN: 1858-0106 e-ISSN: 2502-3926

Volume 17 Nomor 1 Mei 2019, Hlm 76-95

http://jurnal.unmuhjember.ac.id/index.php/FAJ

Waluyo Bambang. (2012). Implementasi Kekuasaan Kehakiman Republik Indonesia. Jakarta: Sinar Grafika

\section{Jurnal}

Hj. Atifaturrahmaniyah (Wakil Ketua Pengadilan Agama Surabaya). (2016). Hukum Acara Peradilan Agama, bahan ajar disampaikan pada Pendidikan Khusus Profesi Advokad (PKPA) yang diselenggarakan oleh Perhimpunan Advokad Indonesia (PERADI) dengan Universitas Airlangga Surabaya pada 7 April 2016.

Sidi Alkahfi Setiawan. (2013). Perlindungan Hukum Pekerja Pemegang Saham Di PT Bank Central Asia Tbk. Fakultas Hukum Universitas Jember 